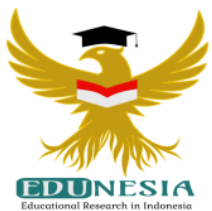

\title{
Hubungan Karakter terhadap Keterampilan Berbicara Mahasiswa Program Studi Akuntansi di Politeknik Mandiri Bina Prestasi
}

\author{
Sinta Diana Martaulina'; Selvie Sianipar² \\ 1,2Pemeliharaan Mesin, Politeknik Mandiri Bina Prestasi Medan, Indonesia \\ ${ }^{1}$ Corresponding Email: sintadianamartaulina@gmail.com, Phone Number : 0813 xxxx xxxx
}

\author{
Article History: \\ Received: Nov 12, 2020 \\ Revised: Nov 15, 2020 \\ Accepted: Nov 16, 2020 \\ Published: Jan 01, 2021
}

Keywords:

Character, Correlation, Speaking Skills.

Kata Kunci:

Hubungan, Karakter, Keterampilan Berbicara.

\section{How to cite}

Martaulina, S.D., \& Sianipar, S. (2021). Hubungan Karakter terhadap Keterampilan Berbicara Mahasiswa Program Studi Akuntansi di Politeknik Mandiri Bina Prestasi. Edunesia: Jurnal Ilmiah Pendidikan, 2 (1): 133-141.

This is an open access article under the $C C-B Y-N C$-ND license

\begin{abstract}
This study aims to make speaking skills that contain character values such as honesty, responsibility, love and respect for others at the college level such as polytechnics. The approach used is a quantitative approach and a qualitative approach. Used to describe the character and speaking skills of students, while a qualitative approach is used to approach speaking skills in interviews. The object of research is students of the AK-2A class of Accounting Study Program which means 34 people in the 2018-2019 academic year (even). The analysis technique in this research is the product statistical analysis of the Karl Person moment. The average character score of the students was 57.85. This value indicates that the character of the student is not good. The average value of student skills skills 71.24 (71\%). This value indicates that the students' speaking skills are good. The correlation between characters and speaking skills is 0.370 and significant at 0.05 levels, because the smaller count is significant than the significant tables, the significant $0.031<0.05$ is significant. In other words, the influence of character on speaking skills is $37 \%$, while the influence of other factors is $63 \%$.
\end{abstract}

\begin{abstract}
Abstrak: Penelitian ini bertujuan agar keterampilan berbicara mengandung nilai-nilai karakter seperti kejujuran, bertanggung jawab, memiliki rasa cinta serta menghargai orang lain di tingkat perguruan tinggi seperti politeknik. Pendekatan yang digunakan adalah pendekatan kuntitatif dan pendekatan kualitatif. Pendekatan kuantitatif digunakan untuk mendeskripsikan karakter dan keterampilan berbicara mahasiswa, sedangkan pendekatan kualitatif digunakan untuk melihat keterampilan berbicara dalam praktik wawancara. Objek penelitian yaitu mahasiswa Program Studi Akuntansi kelas AK-2A yang berjumlah 34 orang Tahun akademik 2018-2019 (genap). Teknik analisis dalam penelitian ini adalah analisis statistik korelasi product momen dari Karl Person. Nilai rata-rata karakter mahasiswa berjumlah 57,85. Nilai ini menunjukkan bahwa karakter mahasiswa kurang baik. Nilai rata-rata keterampilan berbicara mahasiswa berjumlah 71,24 (71\%). Nilai ini menunjukkan bahwa keterampilan berbicara mahasiswa sudah baik. Korelasi antara karakter dengan keterampilan berbicara sebesar 0,370 dan signifikan pada tarap 0,05, karena lebih kecil signifikan hitung dari pada signifikan tabel yaitu signifikan hitung 0,031<0,05 signifikan tabel. Dengan kata lain pengaruh karakter terhadap keterampilan berbicara sebesar $37 \%$, sedangkan pengaruh faktor lain sebesar $63 \%$.
\end{abstract}




\section{A. Pendahuluan}

Pembangunan karakter saat ini menjadi salah satu perhatian serius dari pemerintah yang harus disambut baik. Dalam proses perubahan itu, pendidikan karakter merupakan perubahan yang sangat sulit bagi generasi ini, karena karakter anak-anak sudah terbentuk dalam kehidupan keluarganya. Sementara bangsa yang memiliki karakter kuatlah yang mampu mencapai puncak peradapan dunia. Pendidikan karakter adalah sebuah proses berkelanjutan dimulai dari anak-anak hingga dewasa dan tidak akan pernah berakhir. Ini dapat dilihat dari mahasiswa yang tidak memiliki karakter yang baik, khususnya dalam etika berbicara. Ini disebabkan kurangnya kesadaran mahasiswa untuk memiliki sikap santun, sopan dalam berbicara, dan juga tidak melihat teladan di rumah maupun lingkungannya.

Rumusan masalah dalam penelitian ini adalah: (1) bagaimanakah karakter mahasiswa Program Studi Akuntansi Tahun Akademik 2018-2019? (2) bagaimanakah keterampilan berbicara mahasiswa Program Studi Akuntansi Tahuan Akademik 2018-2019? (3) bagaimanakah hubungan karakter dengan keterampilan berbicara mahasiswa Program Studi Akuntansi Tahun Akademik 2018-2019?.

Karakter memiliki tiga bagian yang saling behubungan: pengetahuan moral, perasaan moral, dan perilaku moral. Karakter yang baik terdiri dari mengetahui hal yang baik, menginginkan hal yang baik, dan melakukan hal yang baik- kebiasaan dalam cara berpikir, kebiasaan dalam hati, dan kebiasaan dalam tindakan. Ketiga hal ini diperlukan untuk mengarahkan suatu kehidupan moral; ketiganya membentuk kedewasaan moral, meskipun berhadapan dengan godaan dari dalam dan tekanan dari luar (Lickona, 2012).

Perkembangan pendidikan karakter di tingkat perguruan tinggi, lebih diutamakan dengan penanaman nilai-nilai tertentu pada diri mahasiswa. Nilai-nilai yang dimaksud adalah yang berguna bagi pengembangan pribadinya sebagai makhluk individu sekaligus sebagai makhluk sosial dalam lingkungan kampus. Pendapat senada juga diungkapkan olehGarmo dalam bukunya" Pengembangan Karakter untuk Anak", bahwa karakter adalah dasar dari jajaran nilai-nilai yang terpilih dalam moral seseorang atau tindakan dan reaksi etis orang tersebut (Siska, 2011). Pendidikan karakter tersebut harus dipraktikkan sehingga titik beratnya bukan pada teori dan diharapkan pendidikan karakter berhasil dimiliki oleh mahasiswa dimana nilai-nilai karakter tersebut akan sangat menentukan emosi positif pada mahasiswa. Emosi positif ini akan memengaruhi etika berbicara mahasiswa dalam hal kesopanan, saling menghormati dan memiliki moral. Dengan pendidikan karakter mahasiswa yang memiliki etika akan tetap ada, sehingga tercipta kembali generasi yang bermoral dan bertanggung jawab serta mampu menunjukkan jati dirinya sebagai manusia yang berbudaya (Garmo, 2013).

Manusia adalah makhluk sosial yang tidak dapat hidup sendiri dan selalu berhubungan dengan manusia lain. Untuk menjalin hubungan tersebut diperlukan suatu komunikasi, yaitu berbahasa. Komunikasi merupakan kegiatan mengungkapkan isi hati kepada orang lain. Cara berkomunikasi dapat dilakukan dengan dua cara, yaitu berkomunikasi verbal dan berkomunikasi nonverbal. Agar komunikasi berjalan dengan baik, diperlukan penguasaan keterampilan berbahasa.Keterampilan berbahasa mempunyai empat komponen, yaitu keterampilan menyimak (listening skill), keterampilan berbicara (speaking skill), keterampilan membaca (reading skill), dan keterampilan menulis (writing skill)." Keterampilan ini merupakan suatu indikator terpenting bagi keberhasilan mahasiswa terutama dalam belajar Bahasa Indonesia. Berbicara adalah kemampuan 
mengucapkan bunyi-bunyi, artikulasi, atau kata-kata untuk mengekspresikan, menyatakan, serta menyampaikan, pikiran, gagasan, dan perasaan (Tarigan, 2017)

Pendapat lain menjelaskan bahwa berbicara adalah wujud pikiran atau perasaan menjadi wujud ujaran atau bunyi bahasa yang bermakna yang disampaikan kepada orang lain (Hutahaean, 2017) Dari pengertian tersebut berbicara adalah sebagai suatu proses komunikasi. Berbicara juga ekspresi kreatif yang dapat memanifestasikan kepribadiannya yang tidak sekedar mengomunikasikan ide belaka, tetapi juga alat utama untuk menciptakan dan memformulasikan ide baru sehingga etika berbicara disebut "berkomunikasi secara efektif dan efisien sesuai dengan etik yang berlaku, baik secara lisan maupun tulisan". Bertolak dari latar belakang di atas, tujuan penelitian ini adalah untuk mengetahui hubungan karakter terhadap keterampilan berbicara mahasiswaProgram Studi Akuntansi Politeknik Mandiri Bina Prestasi, Tahun Akademik 2018-2019 (Genap).

Ada banyak definisi yang berikan para ahli tentang karakter disebabkan karena para ahli memiliki latar belakang dan sudut pandang yang berbeda. Karakter adalah dasar dari jajaran nilai-nilai yang terpilih dalam moral seseorang atau tindakan dan reaksi etis orang tersebut. Karakter sebagai penggambaran tingkah laku dengan menonjolkan nilai (benarsalah, baik-buruk) baik secara eksplisit maupun implisit. (Garmo, 2013)

Buku Character Building untuk Anak-anak mengatakan karakter artinya "mempunyai kualitas positif seperti peduli, adil, jujur, hormat terhadap sesama, dan bertanggung jawab (Lewis, 2004). Jadi, hal-hal positif yang ada di dalam diri kita adalah merupakan karakter.Karakter memiliki tiga bagian yang saling berhubungan, yaitu pengetahuan moral, perasaan moral, dan perilaku moral. Karakter yang baik terdiri dari mengetahui hal yang baik, menginginkan hal yang baik dan melakukan hal yang baik-kebiasaan dalam cara berpikir, kebiasaan dalam hati, dan kebiasaan dalam tindakan.Ada enam aspek yang menonjol sebagai tujuan pendidikan karakter yang diinginkan, 1) kesadaran moral, 2) nilai moral, 3) penentuan perspektif, 4) pemikiran moral, 5) pengambilan keputusan, dan 6) pengetahuan pribadi (Lickona, 2012).

Menurut K. Bertens, secara etimologi etika berasal dari bahasa Yunani kuno (ethos), dalam bentuk tunggal artinya tempat tinggal yang biasa; padang rumput, kandang habitat; kebiasaan, adat, akhlak, watak; perasaan, sikap, cara berpikir. Dalam bentuk jamak (ta etha) artinya adat kebiasaan (Bertens, 2011). Jadi, etika berarti ilmu tentang apa yang biasa dilakukan atau ilmu tentang adat kebiasaan.Menurut Kamus Besar Bahasa Indonesia, etika adalah ilmu tentang apa yang baik dan apa yang buruk dan tentang hak kewajiban moral (akhlaq); kumpulan asas atau nilai yang berkenaan dengan akhlaq; nilai mengenai nilai benar dan salah, yang dianut suatu golongan atau masyarakat. Etika adalah suatu ilmu yang membahas tentang bagaimana kita harus mengambil sikap yang bertanggung jawab berhadapan dengan pelbagai ajaran moral (Nasional, 2015)

Kadir dalam Bertens memberi tiga arti etika, yaitu 1) etika dipakai dalam nilai-nilai dan norma-norma moral yang menjadi pegangan bagi seorang atau suatu kelompok dalam mengatur tingkah lakunya, 2) etika dipakai dalam arti kumpulan asas dan nilai moral, yang dimaksud di sini adalah kode etik, 3) etika dipakai dalam ilmu tentang yang baik atau yang buruk, artinya sama dengan filsafat moral. Dalam perkembangannya etika dapat dibagi dua, yaitu etika perangai dan etika moral (Bertens, 2011).

Keterampilan adalah kecakapan untuk menyelesaikan tugas, kecakapan seseorang untuk memakai bahasa dalam menulis, membaca, menyimak, dan berbicara.Keterampilan hanya dapat diperoleh dan dikuasai dengan cara praktik dan banyak latihan. Jadi 
keterampilan itu sangat erat berhubungan dengan proses-proses berpikir yang mendasari bahasa (Tarigan, 2017). Dari beberapa pendapat di atas, disimpulkan bahwa keterampilan merupakan suatu proses tindakan yang harus dilakukan terus menerus sampai mencapai tujuan yang diinginkan.Berbicara adalah kemampuan mengucapkan bunyi-bunyian, artikulasi atau kata-kata untuk mengekspresikan, menyatakan, menyampaikan pikiran, gagasan, dan perasaan. Berbicara adalah suatu keterampilan berbahasa yang berkembang pada kehidupan anak. Berbicara merupakan kegiatan komunikasi dua arah yang langsung, merupakan komunikasi tatap muka. Tujuan berbicara adalah untuk berkomunikasi (Tarigan, 2017).

Pendapat lain yang merujuk tentang berbicara sebagai proses perubahan wujud pikiran atau perasaan menjadi wujud ujaran atau bunyi bahasa yang bermakna yang disampaikan kepada orang lain (Malini \& Suarni, 2013). Berbicara sebagai suatu proses komunikasi, yaitu suatu peristiwa penyampaian maksud (pikiran atau perasaan) seseorang kepada orang lain dengan menggunakan bahasa lisan atau ujaran hingga maksudnya dapat dipahami.Ada tujuh hal yang harus diperhatikan dalam menilai kemampuan berbicara seseorang, yaitu: lafal, kosakata, struktur kalimat, kefasihan, isi pembicaraan, pemahaman dan bahasa tubuh. Keterampilan berbicara secara umum dapat dibedakan menjadi tiga bagian, yaitu pembicaraan nonformal, pembicaraan semiformal, pembicaraan formal (Hutahaean, 2017). Jadi, Etika berbicara yang baik agar tidak melebar keluar, yaitu 1) fokus pada lawan bicara, 2) menggunakan suara yang baik, 3) jangan mengeluarkan perkataan yang tidak pantas, 4) awali dan akhiri pembicaraan dengan senyuman, 5) berjabat tangan sesudah pembicaraan.

Dari kerangka teoritis di atas, konsep karakter yang digunakan dalam penelitian ini, yaitu konsep karakter Thomas Lickona dan K. Bertens. Konsep karakter Lickona, yaitu (1) pengetahuan moral: kesadaran moral, pengetahuan moral, penentuan perspektif, pemikiran moral, pengambilan keputusan, pengetahuan pribadi; (2) perasaan moral: hati nurani, harga diri, empati, mencintai hal yang baik, kendali diri, kerendahan hati; (3) tindakan moral: kompetensi, keinginan, kebiasaan. Konsep Bertens tentang etika, yaitu etika merupakan tingkah laku, baik-buruk, salah-benarnya seseorang dalam bersikap di masyarakat. Sebaliknya, acuan atau tolak ukur penilaian keterampilan berbicara berdasarkan pendapat Tarigan dan Hutahaean. Konsep keterampilan berbicara merupakan wujud pikiran dan perasaan yang diungkapkan melalui ujaran dan bunyi-bunyian yang bermakna, lewat bahasa tubuh. Konsep Guntur Tarigan, berbicara merupakan alat komunikasi dua arah yang langsung bertatap muka untuk menyampaikan pikiran, gagasan, dan perasaan.

\section{B. Metode}

Penelitian ini dilaksanakan di Politeknik Mandiri Bina Prestasi ini beralamat di Jalan Letjend. Jamin Ginting No. 285-287, Padang Bulan, Medan. Tahap persiapan sampai tahap pelaporan hasil penelitian dilaksanakan selama enam bulan, yakni mulai bulan Februari 2019 sampai dengan bulan Agustus 2019. Subjek dalam penelitian ini adalah mahasiswaProgram Studi Akuntansi Tahun Akademik 2018-2019. Adapun jumlah mahasiswa di kelas ini adalah 34 mahasiswa dan objek penelitian mengetahui pengaruh karakter terhadap keterampilan berbicara mahasiswa Program Studi Akuntansi Politeknik Mandiri Bina Prestasi tahun Akademik 2018-2019 (Genap).Penelitian inimenggunakan tiga sumber, yaitu: 1) tempat dan peristiwa, yaitu proses pembelajaran yang terjadi di kelas AK- 
2A; 2) informan meliputi mahasiswa Program Studi Akunatansi dan staf pengajar/dosen di kelas tersebut, 3) dokumen meliputi catatan lapangan hasil observasi selama proses pembelajaran, mendokumentasikan proses belajar mengajar di kelas.

Teknik pengumpulan data adalah dengan teknik 1) penyebaran angket, yaitu dengan memberikan angket kepada mahasiswaProgram Studi Akuntansi untuk mengetahui karakter mahasiswa tersebut, 2) observasi, yaitu dengan melakukan pengamatan proses pembelajaran di kelas AK-2A untuk mengetahui karakter dan keterampilan berbicara mahasiswa di kelas dan melakukan observasi keterampilan mahasiswa saat melakukan wawancara, 3) wawancara, yaitu dilakukan terhadap staf pengajar/dosen di kelas tersebut.

Untuk menguji kevaliditasan data, maka digunakan 1) tabulasi angket, 2) uji validitas angket, 3) uji reliabilitas angket, 4) deskripsi karakter mahasiswa di kelas yang diambil dari wawancara staf pengajar/dosen, 5) uji normalitas, 6) deskripsi keterampilan berbicara mahasiswa, 7) uji linieritas, 8) korelasi.Analisis data yang digunakan dalam penelitian ini dengan cara kualitatif dan kuantitatif. Pendekatan kuantitatif digunakan untuk mendeskripsikan karakter dan keterampilan berbicaramahasiswa. Pendekatan kualitatif digunakan dalam penelitian ini untuk melihat ketrampilan instrumen praktik wawancara kepada mahasiswa sebagai informan.

\section{Hasil dan Pembahasan}

\section{Deskripsi Karakter Mahasiswa Berdasarkan Penyebaran Angket}

Berdasarkan hasil penyebaran angket yang dilakukan menunjukkan bahwa karakter mahasiswa Program Studi Akuntansi Tahun Akademik 2018-2019 belum maksimal seperti yang diharapkan. Hal ini ditunjukkan dengan nilai rata-rata karakter di bawah 60, yaitu nilai tertinggi 69 dan nilai terendah 49. Nilai karakter tersebut disebabkan oleh pengaruh lingkungan, keluarga yang memiliki pendidikan rendah, kehidupan perekonomian yang rendah, berasal dari desa, tidak melihat teladan yang baik dari orang tua, serta media yang menyajikan informasi yang kurang membangun karakter dirinya sebagai mahasiswa.

\section{Deskripsi Karakter}

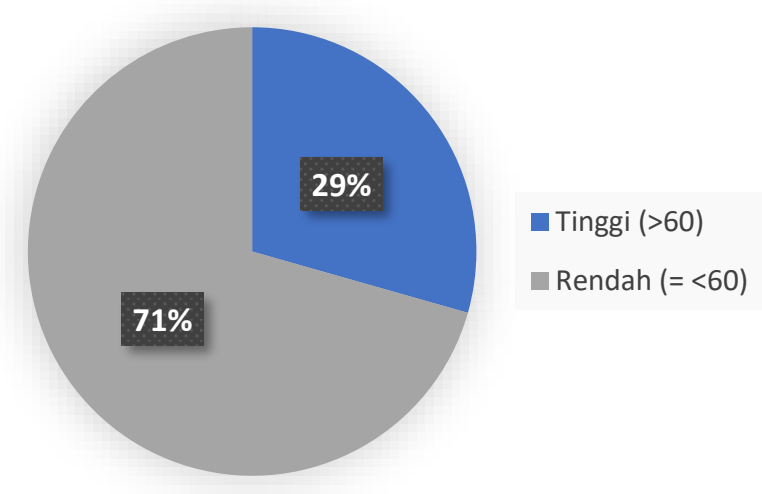

Latar Belakang Karakter:

1. pengaruh lingkungan,

2. keluarga yang memiliki pendidikan rendah,

3. kehidupan perekonomian yang rendah,

4. berasal dari desa,

5. tidak melihat teladan yang baik dari orang tua,

6. serta media yang menyajikan informasi yang kurang membangun karakter dirinya sebagai mahasiswa.

Gambar 1. Karakter Mahasiswa Berdasarkan Penyebaran Angket

Secara lebih rinci penyebaran angket mendeskripsikan beberapa hal sebagai berikut. 
Mahasiswa Kelas AK-2A Program Studi Akuntansi masih suka berteriak di dalam kelas, suka membalas teman dengan kata-kata yang tidak sopan, masih suka berbohong untuk membela kesalahan orang lain, tidak jujur pada saat ujian, tidak mengerjakan tugas yang diberikan staf pengajar/dosen, melanggar peraturan (terlambat masuk ke kelas, berpakaian tidak rapi), tidak memberi salam saat masuk ke kelas, karakter tersebut di atas yang masih dilakukan mahasiswa Kelas AK-2A Program Studi Akuntansi.

\section{Deskripsi karakter mahasiswa berdasarkan observasi di kelas AK-2A}

Hasil observasi di kelas menunjukkan karakter mahasiswa di dalam kelas saat proses belajar mengajar. Gambaran karakter mahasiswa Program Studi Akuntansi yang terlihat seperti suka berkata tidak sopan, bersikap kasar, suka berteriak, jahil (suka mengganggu teman), suka membalas perbuatan orang lain, tidak menjaga kebersihan diri, tidak menjaga kebersihan lingkungan kelas, tidak peduli dengan orang lain, kurang menghormati staff pengajar/dosen maupun orangtua/wali, tidak bertanggungjawab atas tugas yang diberikan staf pengajar/dosen.

\section{Karakter Observasi Kelas}

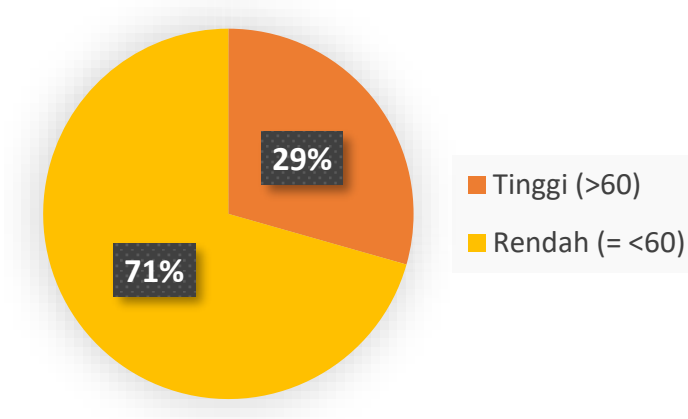

Karakter mahasiswa :

1. suka berkata tidak sopan, bersikap kasar,

2. suka berteriak, jahil (suka mengganggu teman),

3. suka membalas perbuatan orang lain,

4. tidak menjaga kebersihan diri, tidak menjaga kebersihan lingkungan kelas,

5. tidak peduli dengan orang lain, kurang menghormati staff pengajar/dosen maupun orangtua/wali,

6. tidak bertanggungjawab atas tugas yang diberikan staf pengajar/dosen.

Gambar 2. Karakter Mahasiswa Berdasarkan Observasi di Kelas.

Banyak mahasiswa Program Studi Akuntansi Kelas AK-2A ini tidak memperhatikan staf pengajar/dosen saat proses belajar mengajar berlangsung. Terlihat kondisi mahasiswa, ada yang melamun, ada yang memperhatikan sambil duduk santai sambil bersandar kedinding, ada yang mengantuk, ada yang asyik menulis, ada yang malas, ada mahasiswa asyik dengan dirinya sendiri. Hanya mahasiswa beberapa mahasiswa saja yang memiliki respon yang baik dan memperhatikan saat dosen mengajar. Hal itu terlihat saat dosen bertanya mahasiswa tersebut dengan cepat menjawab dengan baik.

\section{Deskripsi karakter mahasiswa berdasarkan wawancara dengan dosen/staf pengajar di kelas AK-2A.}

Hasil deskripsi karakter mahasiswa berdasarkan wawancara dengan dosen/staf pengajar yang dilakukan kepada limabelas mahasiswa mewakili gambaran seluruh mahasiswaKelas AK-2A (sampel penelitian), Tahun Akademik 2018-2019. Kelima belas mahasiswa tersebut diantaranya lima orang mahasiswa yang berprestasi baik (tinggi), lima orang mahasiswa yang memiliki prestasi sedang, dan lima orang yang memiliki prestasi 
rendah. Ternyata bagi mahasiswa yang memiliki prestasi tinggi masih ditemukan karakter yang kurang baik, seperti suka mengganggu teman, mengucapkan perkataan yang tidak sopan, suka menyebutkan nama orang tua temannya, suka berteriak, tidak tertib. Lain halnya dengan mahasiswa yang memiliki prestasi yang rendah, lebih memiliki karakter yang lebih baik.

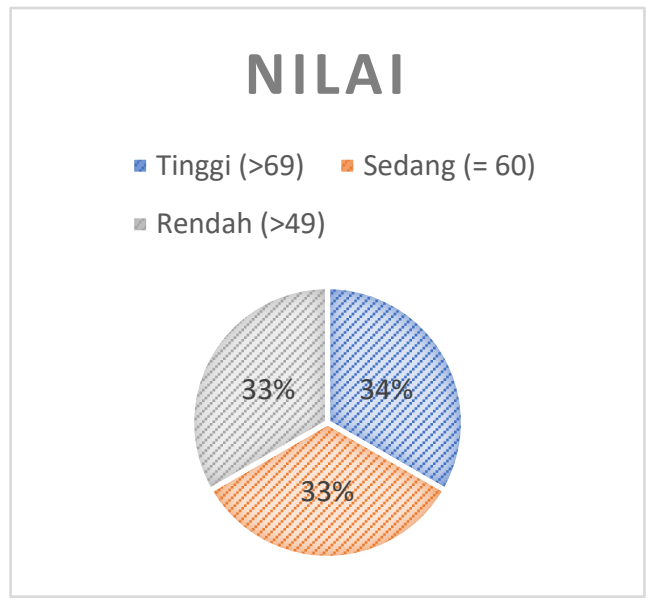

Karakter mahasiswa :

1. suka mengganggu teman,

2. mengucapkan perkataan yang tidak sopan,

3. suka menyebutkan nama orang tua temannya,

4. suka berteriak,

5. tidak tertib.

Gambar 3. Karakter mahasiswa Berdasarkan Wawancara dengan Staf Pengajar.

Gambaran karakter mahasiswa Program Studi Akuntansi, kelas AK-2A yang diperoleh berdasarkan dialog maupun wawancara kepada staf pengajar/dosen secara umum cukup baik, meskipun tidak terlalu signifikan. Jadi, untuk meningkatkan karakter mahasiswa tersebut perlunya peningkatan mutu pendidikan berbasis karakter harus lebih ditingkatkan. Salah satu cara yang harus dilakukan adalah dengan melakukan pembinaanpembinaan secara kontiniu terhadap mahasiswa. Hal ini merupakan suatu kewajiban dan tanggung jawab bagi seorang pendidik dalam meningkatkan mutu dan kualitas karakter mahasiswa.

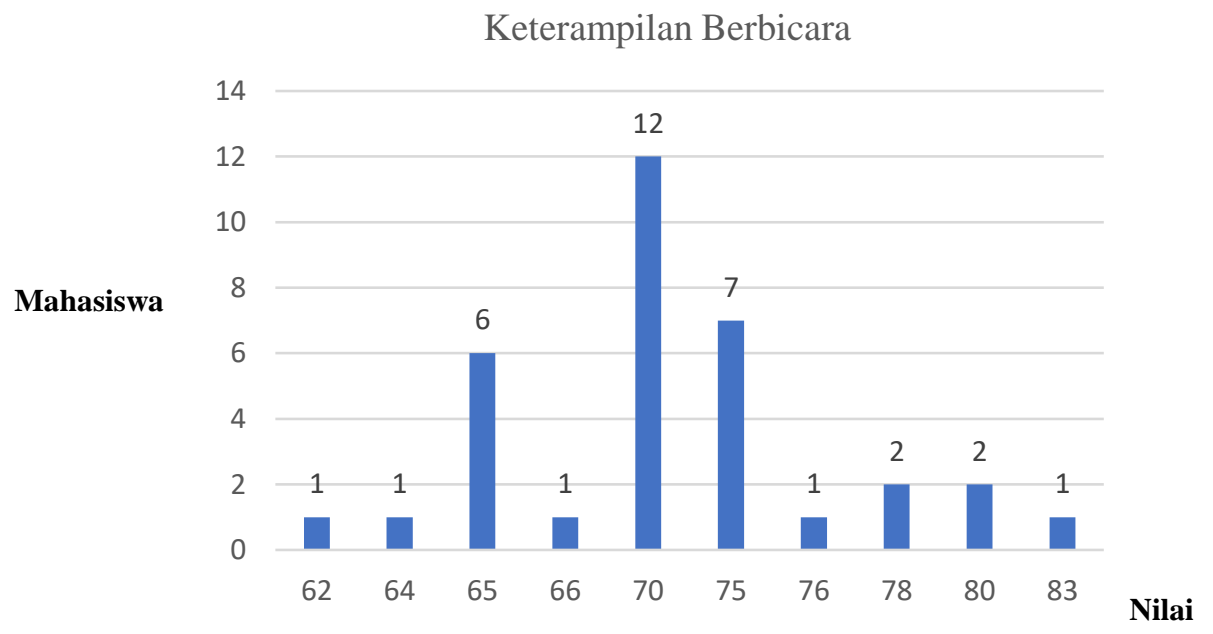

Gambar 4. Keterampilan Berbicara Mahasiswa Program Studi Akuntansi Kelas AK-2A 


\section{Uji Linieritas}

Hasil uji linieritas diketahui bahwa variabel independen yang dimasukkan ke dalam model adalah karakter dan variabel dependennya adalah keterampilan berbicara. Nilai konstata (a) adalah 36.566. Hal ini dapat diartikan jika koefisien karakter bernilai 0, maka keterampilan berbicara bernilai negatif yaitu 36.566. Nilai koefisien regresi variabel karakter (b) bernilai positif yaitu 0.299. Hal ini dapat diartikan setiap peningkatan sebesar 0.299, maka keterampilan berbicara juga akan meningkat sebesar 0.299.

\section{Uji Korelasi}

Korelasi antara karakter dengan keterampilan berbicara sebesar 0,370 dan signifikan pada tarap 0,05 karena lebih kecil signifikan hitung dari pada signifikan tabel (Signifikan hitung 0,031<0,05 signifikan tabel). Dengan demikian dapatlah dikatakan bahwa karakter berhubungan dengan keterampilan berbicara atau karakter mempengaruhi keterampilan berbicara mahasiswa Program Studi akuntansi. Besarnya hubungan karakter terhadap keterampilan berbicara sebesar, yaitu 0,370 atau 37\%. Pengaruh karakter terhadap keterampilan berbicara mahasiswa Program Studi Akuntansi Politeknik Mandiri Bina Prestasi untuk Tahun Akademik 2018-2019 (Semester Genap) sebesar 37\%, sedang pengaruh faktor lain sebesar $63 \%$.

\section{Kesimpulan}

Berdasarkan hasil pembahasan di atas dapat disimpulkan hal-hal berikut ini. Nilai rata-rata karakter mahasiswa Program Studi Akuntansi Politeknik Mandiri Bina Prestasi Tahun Akademik 2018-2019 (Genap) berjumlah 57,85. Nilai 57,85 menunjukkan bahwa karakter mahasiswa yang diteliti dalam kategori yang belum dapat diharapkan (kurang baik) yang ditunjukkan pada nilai rata-rata karakter mahasiswa yang bersangkutan di bawah nilai 60. Nilai karakter mahahasiswa tertinggi adalah 69 dan perolehan karakter nilai terendah adalah 49 . Nilai karakter di bawah 60 sebanyak 24 mahasiswa atau $71 \%$ dan 10 orang bernilai di atas 60 atau $(29 \%)$.

1. Nilai rata-rata keterampilan berbicara mahasiswa berjumlah 71,24 . Nilai 71,24 menunjukkan bahwa keterampilan berbicara mahasiswa sudah baik karena nilai ratarata keterampilan berbicara di atas nilai 60 . Nilai tertinggi berjumlah 83 dan nilai terendah 62. Nilai tertinggi 83 berjumlah 1 mahasiswa atau 2,94\%. Sebanyak12 mahasiswa memperoleh penilaian keterampilan berbicara 70 atau 35,29\%. Demikian halnya dengan mahasiswa yang memperoleh penilaian di atas 70 atau 35,29\% sebanyak 12 orang juga. Mahasiswa yang mendapatkan nilai keterampilan berbicara di bawah 66 sebanyak 8 mahasiswa atau $23,52 \%$.

2. Nilai koefisien korelasi antara karakter dengan keterampilan berbicara sebesar 0,370, maka dapat disimpulkan bahwa hubungan antara karakter dengan keterampilan berbicarakorelasi rendah. Korelasi antara karakter dengan keterampilan berbicara sebesar 0,370 dan signifikan pada taraf 0,05, karena lebih kecil signifikan hitung dari pada signifikan tabel, yaitu signifikan hitung 0,031<0,05 signifikan tabel. Dengan demikian dapatlah dikatakan bahwa karakter berhubungan dengan keterampilan berbicara. Besar hubungan karakter terhadap keterampilan berbicara sebesar 0,370 atau $37 \%$. Dengan kata lain pengaruh karakter terhadap keterampilan berbicara sebesar $37 \%$, sedangkan pengaruh faktor lain sebesar $63 \%$. 


\section{Daftar Pustaka}

Bertens, K. (2011). Etika: Seri Filsafat Atma Jaya 15. Jakarta: Pustaka Utama.

Garmo, J. (2013). Pengembangan Karakter untuk Anak-Anak. Jakarta: Kesaint Publishing.

Hutahaean, B. (2017). Bahasa Indonesia Terapan. Kisaran: -.

Lewis, B. (2004). Character Building untuk Anak-Anak. Batam: Karisma Publishing Group.

Lickona, T. (2012). Educating For Character. Jakarta: Bumi Aksara.

Malini, N. K. S., \& Suarni, N. K. (2013). Penerapan Model Pembelajaran Picture and Picture melalui Media gambar untuk meningkatkan keterampilan berbicara pada anak Taman Kanak-kanak. Jurnal Pendidikan Anak Usia Dini Undiksha, 1(1).

Muslich, M. (2010). Pendidikan Karakter: Menjawab tantangan Krisis Mulitidimensional. Jakarta: Bumi Aksara.

Nasional, D. P. (2015). Kamus Besar Bahasa Indonesia. Jakarta: Balai Pustaka.

Siska, Y. (2011). Penerapan metode bermain peran (role playing) dalam meningkatkan keterampilan sosial dan keterampilan berbicara anak usia dini. J. Educ, 1(1).

Tarigan, H. G. (2017). Berbicara sebagai Suatu Ketrampilan Berbahasa. Bandung: Angkasa. 